\title{
Studies in Canadian Literature
}

Études en littérature canadienne

\section{The Spatial Politics of Homosociality in Austin Clarke's In This City}

\section{Cornel Bogle}

Volume 43, Number 1, 2018

URI: https://id.erudit.org/iderudit/1058066ar

DOI: https://doi.org/10.7202/1058066ar

See table of contents

Publisher(s)

University of New Brunswick, Dept. of English

ISSN

0380-6995 (print)

1718-7850 (digital)

Explore this journal

Cite this article

Bogle, C. (2018). The Spatial Politics of Homosociality in Austin Clarke's In This City. Studies in Canadian Literature / Études en littérature canadienne, 43(1).

https://doi.org/10.7202/1058066ar

All Rights Reserved (C) Studies in Canadian Literature / Études en littérature canadienne, 2019
This document is protected by copyright law. Use of the services of Érudit (including reproduction) is subject to its terms and conditions, which can be viewed online.

https://apropos.erudit.org/en/users/policy-on-use/ 


\title{
The Spatial Politics of Homosociality in Austin Clarke's In This City
}

\author{
Cornel Bogle
}

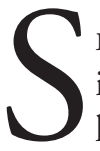

et mostly in Toronto, Austin Clarke's collection of short stories In This City explores the alienation, chaos, and joy of city life through the eyes of the inhabitants of and visitors to urban spaces of North America. The collection is directly concerned with the relationship between self and metropolitan spaces encountered by the characters, and the malleability of spatiality emerges as an important feature. Clarke's own life becomes a reference point for viewing the text as an archive of self and spaces, for Toronto moves from the mere posturing of multiculturalism as a legal concept to rich cultural and racial diversity. Clarke situates it as a textured milieu in which issues of racialized and gendered modernity can be explored (Chariandy xii). In This City is rife with stories of men who must navigate various spaces in relation to their performances of masculinity. These performative acts are not only mediated by spatialities but are dependent on them.

That Clarke is interested in possibilities for masculinities in the space of the North American city is not new. His fiction and poetry set in Toronto and other urban spaces in North America have largely engaged with masculinity as a fluid concept, one largely absent from the generally hypermasculine expressions of manhood in his fiction and memoirs based in the Caribbean. This is not to say that the Caribbean spaces in many of his works do not engage with notions of fluid masculinities; they are evident in characters such as Sarge in The Polished Hoe as well as several individuals in his memoir Growing Up Stupid Under the Union Jack. However, Canada serves as a site for a greater exploration of various performances of "masculinity," and this might have to do with the legal frameworks in North America that allow for different expressions of masculinity lacking in the Caribbean.

During the 1960s, as Clarke began writing in Canada, immigration reforms allowed for an increase in migration rates from the Caribbean as preferential policies directed at attracting European migrants were replaced by a skill-based point system aimed at expanding the Canadian 
labour force (Milan and Tran 3). This decade of increased immigration among Caribbean nationals to Canada was also characterized by changes to the law in Canada that addressed the rights of its non-heteronormative citizens. It was in 1967 that then Minister of Justice Pierre Trudeau introduced the Criminal Law Amendment Act, concerned among other things with the decriminalization of homosexual acts between consenting adults as well as the implementation of progressive abortion and contraceptive rights (Price). With the passing of the bill in 1969, Canada established a metanarrative as a space of progressiveness, from a legal standpoint if not from lived realities. Indeed, this characterization of Canada is evident even before 1969, for characters in Clarke's 1967 The Meeting Point, while expressing ambivalence about the diasporic experience, nonetheless position Canada as a space that embodies liberalism. Boysie, a central figure in the Toronto Trilogy, goes as far as describing Canada as "a star o' progress" (77), signalling the nation's difference not only from the rest of North America but also from his homeland of Barbados. ${ }^{1}$

As Daniel Coleman notes in Masculine Migrations: Reading the Postcolonial Male in "New Canadian" Narratives, the characters in Clarke's short fiction "are very conscious about acting male, about using all the techniques of drama, from gestures to costumes to props and sets" (32). In centring the performativity of enterprising masculinities in Clarke's Nine Men Who Laughed, Coleman points to Judith Butler's work in Gender Trouble: Feminism and the Subversion of Identity, which identifies gender as "an identity tenuously constituted in time, instituted in an exterior space through a stylized repetition of acts" (179). Coleman's mention of "sets" and Butler's location of the constitution of gender "in an exterior space" draw attention to the fact that the use of spatiality has not been given great attention by scholars of Clarke's work in the past.

The rise of spatial theory and greater observations of the possibilities of interdisciplinary studies have opened a means by which masculinities and spatial theory can be employed to explore issues of homosociality and belonging. Phanuel Antwi, in recognizing this opening, has offered an intervention in his reading of Clarke's short story "Sometimes, a Motherless Child." Through the adoption of a uniquely interdisciplinary lens, Antwi suggests that interpretations of masculinities in Clarke's work have now become understood "as (discursively) multiple, open, and always contingent on environment" (197). Spatiality emerges as a 
site of engagement in the production of identities; the reading of spaces and the homosocial relations that mark them in Clarke's work allows for new understandings of both immigrant masculinities and modernities. Henri Lefebvre's configuration of space as intertwined with social reality as well as socially produced, and elaborations of his theorization of space by Gloria Anzaldúa, Edward Soja, and others, have enabled the conceptualization of space and spatiality to have larger resonances with the bodies that interact with them. Indeed, space can no longer be seen as a plane on which subjects merely act; rather, space is viewed as being bound up with the body, gender, sexuality, race, and positionality. This interconnectedness is not manifest in space in lateral ways; rather, it emerges as a complex field of relations among individuals, social life, and space. Therefore, if we are to accept Martin Heidegger's claim that as human beings we "make room," "give space," and "let entities within the world be encountered" (qtd. in Ortega 26), alongside Lefebvre's conception of space as socially produced, then the experience of inhabiting space is not only concerned with how these spaces are produced and transformed by individuals but also shares an interest in how collectively produced spatiality has transformed the subjects themselves in ways not immediately resonant with the social realities that prefigured them.

Homosociality finds itself linked to spatiality through the affectivity central to the relationships in which men in Clarke's work engage. Eve Kosofsky Sedgwick, who popularized homosociality in critical discourse, defines these relations as "social bonds between persons of the same sex," which can be characterized as a mutual desire or recognition of the other that serves as "the affective or social force . . that shapes an important relationship" (1-2). Homosociality is not synonymous with homosexuality; rather, these relations among men become queered by both the spaces that they inhabit and the bonds that emerge.

Taking my cue from Coleman and Antwi, I contribute to and expand on the discussion of Clarke's short fiction by suggesting the spatial politics at play in the production and performance of masculinities. The stories "Initiation" and "A Short Drive" in In This City are marked by some form of spatially constructed homosociality. Same-sex relations in these stories emerge in the figure of paternalism, the mentor-student archetype, as well as peer and queer relations. These relationships are framed and informed by spaces in which these men encounter each other, such as clubs, homes, cars, streets, and bars. It is in these spaces, 
I contend, that cultural constructions of masculinity are broken down and spatially constructed experiences of homosocial relations reveal the liminality of self (both as a masculine and as a human subject) and expose the malleability of masculinities and spatialities. Moreover, it is in these spaces that Clarke positions Afro-Canadian masculinity as entangled with a distinctly African American aesthetic and posture. In doing so, he intimates the failure of Canada to offer spaces for progressive black masculinities, a failure that leads to the need for a broader transnational masculinity that borrows much of its language and many of its postures from the black pride movement of the United States.

Clarke's early work as a journalist for the Canadian Broadcasting Corporation (CBC) took him to Harlem, where he interviewed the African American activist Malcolm X, who would become a recurring figure in much of his work, specifically The Meeting Point and In Your Crib. By his own admission in his memoir 'Membering, Clarke was "terrified" at the prospect of interviewing the activist, whom he had read about "in Ebony, in Life, in Newsweek, in the New York Times Sunday Magazine, even in Muhammad Speaks, his own magazine" (173). However, despite his initial apprehension, his interview would become the centrepiece of his 1963 CBC Radio documentary Harlem in Revolt. A little over a year later, in December 1964, Malcolm X would give a speech to Peace Corps Workers in New York City, some two months before his assassination. In this speech, he proclaimed his belief "in the brotherhood of man, all men," and spoke in detail about this homosocial and highly politicized vision of collective activism. The mention of "brotherhood" at various points throughout his speech, and multiple references to a transnational black identity centred on Harlem in Clarke's work, signal an important place to begin reading the construction of black masculinities in the imaginations of Clarke and other black writers in North America in the 1960s and beyond.

The story "Initiation" emerges as one such moment in the Barbadian Canadian writer's oeuvre that presents masculinities centred on the black pride movement and African American culture. Throughout the story, men perform various postures of hypermasculinity in their interactions with each other. Through their conscious posturing of masculine identities associated with both geographical and temporal spaces, the men reveal their expressions of manhood as coping mechanisms 
for insecurities about the queered possibilities of black selfhood and homosociality.

Narrated from the perspective of a West Indian-born professor at York University, the story follows his plunge into the world of his student Barrington and his associates. The narrative documents the privileged professor's immersion into the Jane and Finch neighbourhood of Toronto and his interactions with other men in a cramped room. These men enact performances of masculinity ranging from hypermasculine postures of smoking, drinking, and loudly discussing (cultural) revolution to moments of intimacy, confusion, and insecurity. The extent to which these movements along a continuum of masculine expression are linked to spatiality is evident by how the actions of these men are situated by space and through references to other geographical spaces, such as Harlem, that conflate certain expressions of masculine performance with urban areas. "Initiation," more so than other stories in In This City, signifies how this spatial disorientation, evident in the constant references to other locales, is representative of a broader fluid politics of identity. Harlem becomes a spatial metaphor for both hypermasculinity and the fluidity of identity that emerges in the vulnerabilities of men who come together and try to create a safe space. Harlem is referred to at least sixteen times throughout the story, and it is often prefigured by the phrases "I could be in" and "as if I was in," suggesting a sense of association between certain masculinities and certain urban spaces.

David Chariandy writes that the inclusion of this type of black pride aesthetic and Harlem is rooted in "Clarke's own lifelong interest in ... American black nationalism" (xiii). Having lived in the United States for many periods of his life - employed as a journalist, a cultural attaché at the Barbadian Embassy in Washington, and as a visiting scholar at several American institutions - Clarke was aware of African American masculinity and used it in his construction of black homosociality in Toronto. Harlem in the popular black imagination exists not only as a cosmopolitan space but also as a space that allows fluidity, progress, and indeed queerness, as has been evident in well-known figures (e.g., Audre Lorde, James Baldwin, and Lorraine Hansberry) who have been the focus of recent scholarship invested in queer recovery. This space of fluid expression of masculinities along the continuum ranging from stereotypically "hypermasculine" performances through diction to queered masculinities is marked by notions of what Dionne 
Brand would refer to, in the title of her first novel, as the desire to be "in another place, not here." When the narrator refers to the room and the surrounding community as "this Toronto version of Harlem" (In This City 38), he is not merely conflating the notion of a masculinity rooted in a black pride aesthetic evident in the men but also suggesting that certain spaces are associated with and privileged as sites in which expressions that veer from merely performative gestures of hard masculinity can emerge.

Richard Dennis and Coral Ann Howells, in their introduction to an issue of The London Journal of Canadian Studies on Geography, Gender, and Identity in Canadian Literature, position "the search for self-identity as a spatial journey" (4). They note that many key literary works that emerge from the nation embody a "focus on boundaries: boundaries which may seem definite and impermeable, but are actually fluid and shifting" (4). Canadian literature, then, is marked by an interest in the relationship between space and identity in creating narratives of the nation and guiding public discourse as well as a focus on how raced and gendered expressions are configured because of space. As a space on its own, Canada has had dubious associations with race that can be traced to its relationship to its Indigenous peoples and what Rinaldo Walcott terms the "'absented presence' of Canada's others" ("Tough Geography" 37). Consequently, these marginalized figures within Canada, and other spaces in which they are subject to a process of erasure, must enact a means of asserting their presence. The men in "Initiation" enact a form of marronage "marked by the establishment of alternate communal spaces of gathering" (Cummings 329).

Clarke suggests that men need safe spaces wherein their insecurities can emerge and they can be outside the gaze of a largely white and essentializing society. Racial oppression is a major part of the production of black masculinity and the gathering of black men, particularly in a predominantly heteronormative and white nation, where they are often subject to heightened vigilance and policing. Michael Bucknor has suggested that "maroon intimacies are associated with guerrilla warfare against dominant power structures using strategies of improvisation, transgression, and rebellion" (65). The references to revolution and militancy in the story "Initiation" reflect the mobilization of an intimacy marked by the sensibilities of the maroon tradition. In "Sometimes, a Motherless Child" and The Meeting Point, Clarke suggests that the 
public space becomes a danger to black men and results in violence to the black male body, and both stories depict fatal violence against black men by the police. Indeed, in "Sometimes, a Motherless Child," the protagonist, BJ, is warned by his mother that he better be careful, "living in this place with all the things happening to black people, to men and boys like you" (In This City 332). This warning seems to be necessary since his death as a result of police brutality is the inevitable result of his being both black and male. Clear in Clarke's work is that black men, wherever or however they choose to gather, are always subject to the gaze of outsiders and subsequently more susceptible to violence.

Beyond how those outside the homosocial experience can perceive these men as dangerous because of racist discourse, there is the extent to which gender operates as problematic when men gather. Barrington's aunt is mentioned at various points in the story but is never suggested to be in the room, nor is she ever heard or identified. Although the space emerges as one that can facilitate the breaking down of certain codes of hypermasculinity, it still reinforces gendered hierarchies. I do not intend to undermine the significant observations about the positioning of women in Clarke's work (see, e.g., Barrett et al.; Sanders). Yet I would suggest that not all of them be read as attempts to silence or misrepresent. I find Sedgwick's assertion that, "in any male dominated society, there is a special relationship between male homosocial (including homosexual) desire and the structures for maintaining and transmitting patriarchal power" (25) as largely essentialist and worthy of re-examination in relation to black masculinity, in which blackness itself is subject to structures of control and containment. Broad criticism of Clarke's treatment of women is necessary, but if asserted as totalizing can result in little room in which homosocial interactions can be read outside the view of reinforcing codes of gendered dominance. For Clarke, this is what must be deconstructed - how spaces for a range of masculinities to emerge are often policed, politicized, and problematized by white bodies without concern for how these black bodies and their masculinities have been formed.

Beth Ellen Kramer argues that "homosocial bonds between men reflect a battle to own a masculine image that is rooted in patriarchal control" (9). Certainly, construction of the space as marked by a "revolutionary" masculinity intent on maintaining a masculine space that does not involve women is evidence of this. However, one should note how 
readers of "Initiation" are initially positioned to perceive the space and how it changes because of the homosocial bonding. The apartment in which the men encounter each other is described as "gloomy, lampless," and its "windows were closed against the life outside" (29-30). Men encountering each other in darkness has queer implications. The dark room is symbolic of how masculinities operate and of how homosocial encounters by black men in North America are policed by the outside world and need to be guarded or obscured. The darkness, then, allows for movement along the continuum of masculine expression as well as for the supposed escape of certain coping mechanisms needed for the outside world as black men. Yet one would also be right to suggest that this escape is another coping mechanism, albeit one structured around other men.

The professor who functions as the narrator and interlocutor initially positions the men in the room as dangerous and likely to fit the stereotype of rough black men. Inclusion of the figure of the black professor is representative of the precarious space in which Clarke and other Afro-Canadian men operate. That is, a privileged individual endorsed and legitimized by institutions of authority whose existence and achievements repudiate popular essentializing narratives of black masculinity. Clarke plays with this archetypal figure in several ways, whether through his inability to truly inhabit certain spaces, as in "Initiation," or through his failure (the figure is usually associated with secondgeneration Afro-Canadians in Clarke's work) to perform black masculinity, as evident in the figure whom the persona chastizes in In Your Crib. Many of the assumptions made by the narrator in "Initiation" are informed by the space in which he finds himself. He repeats the phrase "in this section of the city" (25), suggesting that the space he has entered is marked by certain histories and narratives. Indeed, the Jane and Finch neighbourhood is known as a predominantly black community, marked by and publicly perceived as a space rife with criminal activities and lowincome households. He confesses that he often reads "in the newspapers about raids, and of black men being manacled and thrown into paddy wagons, ... and one showed the house from which the men were taken. It could have been this room" (35). Despite this initial characterization of the men's hard and even criminal masculine postures, evinced by his assumptions as well as photos of the men holding guns and conducting illicit transactions, they undergo metamorphoses as their masculinities 
shift from more rigid performances to softer expressions, humorously so, through marijuana. The narrator observes that "the thing we were smoking made us all soft in the room" and then links this softening of masculine expression to spatiality as he notes that it "made the room itself smaller than it was" (31). The perception of the space changes as the expressions of masculinity are altered. Moreover, the notion of men going "soft" has sexual connotations, suggesting that in safe spaces men break from hypermasculine and hyperconscious heteronormativity and become queered. The notion further represents a different type of masculinity, as opposed to the hypermasculinity often centred on one's sexual prowess, not only connoting a certain degree of effeminacy for many men but also suggesting heteronormative impotence within a hypermasculine frame.

Clarke's oeuvre has multiple moments of public homosociality, such as in the rum bar in Proud Empires and The Origin of Waves or the car in The Meeting Point and In Your Crib. However, the men in "Initiation" are positioned as vulnerable and thus need the private space to allow themselves to become more than what is necessary to meet the public gaze and expectation of black masculinity. Although they exhibit a certain type of roughness early in the text, eventually they are revealed as insecure and subject to rapid changes and movements along the continuum of masculinity and are indeed protected by the physicality of the space that they inhabit. Thus, even as Kramer and Sedgwick argue that the homosocial experience is centred on exercising patriarchal power, it also emerges as a space in which men can reclaim the ability to recognize themselves as opposed to being recognized and stereotyped by others. Although the space allows for great fluidity, initially it is also suggested to be tense, for the experience of homosociality produces alienation among the men. This is an early indication of the type of emotional vulnerability that men can experience in this space, even that which stems from their experiences with each other. There is an extent to which the narrator himself, on recognizing the varied masculine figures in the room, attempts to enact a performance of similar masculinities to compensate for his insecurities. He admits his feelings of vulnerability since he believes that he is an outsider in this homosocial gathering: "They had forgotten me again. I did not exist any longer, against their tight ritual and understanding" (40). At an earlier point in the text, he discloses that "I wanted to be accepted, and 
regarded as cool" (31). This invoking of "cool" calls to mind the work of Richard Majors and Janet Mancini Billson on the "cool pose." They argue that it is an integral aspect of African American masculinities in its strategic projection of "control, strength, and pride" (2), essentially how Barrington and his friends are characterized by the much older and supposedly uncool narrator. However, this posture of "coolness" by the other men, which renders the narrator insecure, is a strategy enacted by black men "to ward off the anxiety of second-class status. It provides a mask that suggests competence, high self-esteem, control, and inner strength. It also hides self-doubt, insecurity, and inner turmoil” (5). Thus, the encounter becomes one in which many masked and vulnerable figures can come together; although initially they maintain this posture, slowly it fades away.

Beyond the experience of group homosociality, the relationship between the elder and the student operates as a central homosocial interaction in "Initiation." 3 The text is keen on inverting the model through spatiality as the elder, in this case the narrator and professor, encounters an alien space that disorients him not only spatially but also in terms of his acknowledged role and position in the relationship with his student. The student becomes the guide, and, though their relationship before entering this space emerges as peculiar in its intimacy, further barriers in their relationship are broken because of their encounter in this space with other men. After witnessing what appears to be an exchange of drugs, the narrator tellingly admits that "I was beginning to doubt that I knew this young man who had come to my office and my downtown home so often" (29). His observation suggests a shift in his perception of Barrington's masculinity in this space. Moreover, potentially, it queers the two figures since the narrator notes that Barrington has visited him at his "downtown home so often," hinting at a relationship that goes beyond the typical student-teacher one. They become queered through the sharing of domestic spaces and through the intimacies that result from such associations that go beyond the typified codes of black heterosexual masculinity. Moreover, crossing the student-teacher boundary is suggestive of a further act of disavowing existing normative codes of relating among black men. This is particularly evident as Barrington says "It ain't nothing brother" in response to the professor. His admission that "This was the first time he called me brother" (34) suggests that this tiny apartment allows for new intimacies to be forged and 
existing relationships to be transformed. Homosexual panic is played out in the text, and the intimacy, afforded in spaces of homosociality that exist outside an explicitly homosexual frame, allows for men to achieve bonds that go beyond archetypes that exist for heterosexual black men.

The ending of "Initiation" situates the experience of homosocial transgression in a particular space. The narrator and Barrington have now moved to a bar, and their relationship and the intimacy built between them in the room are no longer relevant in the outside world in the light of day. As the narrator emerges from the bathroom of the bar, Barrington remarks that his professor has changed out of his camouflage attire (which significantly can be read as his entrance into the homosocial space intended to be inconspicuous) and into more semiformal clothes. When asked about the camouflage, the narrator replies that he "left it for a chap I saw in the men's room" (53), another space of homosociality briefly evoked in the text. There is a queer moment as Barrington asks, rhetorically, "In the men's room?" (53), which leaves readers at the end of this story to question their assumptions about the spaces in which men encounter each other throughout the story. The moment is ironic since it is not the space of the bathroom that emerges as queer but the tiny apartment room that he and the other men inhabited. When the professor remarks that "Now when we get back to York ..." (53; ellipsis in the original), which ends the story, he reveals how entrance into the outside world has shifted the relationship between the two men. The transgression of boundaries of masculinity evident in the room no longer carries weight in the outside world. The relations and hierarchies are restored at the end, and in shedding the camouflage outfit the professor puts on another mask, and the stifled, restrictive ways in which men cope with the outside world and how they interact with other men are brought into the light.

Masculinity within homosocial encounters is positioned as vulnerable because of its inherent performativity and the insecurities that emerge from a space undefined by expected codes of expression that might exist for the outside world. As Brenda Boudreau asserts, "if masculinity is a display ... it is also vulnerable to being revealed as false; if it can be worn, it can also be stripped away, demonstrating the tenuousness of masculinity" (qtd. in Sargent 7). I extend that idea and suggest that being revealed as false is not the only pervasive insecurity 
that men must contend with in their interactions with other men in spaces; they must also contend with the ability of spaces to reveal their masculinities (coupled with their sexualities) as fluid, queer, and vulnerable. Narratives of hypermasculine performance have been subject to scrutiny by Butler and Sedgwick, who point to gestures and bonds as markers of a performance of normative heterosexual masculinity. The work of contemporary gender theorists, such as Afsaneh Najmabadi, has been essential in conceptualizing the connections between gender performance and sexuality. Najmabadi contends that "modernity, bringing gender into visibility and masquerading sexuality, made gender the template for the legibility of sexuality" (238), which informs a reading of In This City wherein the heightened expressions of hypermasculinity guided by specific codes of behaviour are mobilized by men to compensate for their sense of queerness, in turn revealed through subconscious expressions. Throughout the collection, characters reveal themselves to be haunted by the spectre of the homosexual in their obsessions, memories, and utterances. In the story "Naked," as the narrator becomes increasingly paranoid in his search for the man who has broken into his apartment, he reveals the extent to which the violation of space is also a violation of his masculinity and confidence in his sexuality. His fervent hunt for the thief borders on a sensual subconscious desire, for his fantasizing centres not on the vulnerability that one feels after being robbed but on a desire to understand the thief in more intimate terms. The body becomes synonymous with the space of the home since being robbed results in a "naked feeling" (148). Language associated with sexual assault is used to emphasize the feeling of violation: "[T]he walls were unmolested. Pictures and paintings . . . were untouched” (152). Clarke positions the entering of the narrator's home as an intimate/sexual act between the men. Haunting images of intimacy between them are hinted at by the narrator, such as when he observes that "someone had rubbed his unwashed fingers over and had washed his lips on the lid I had put to my lips; and that this could have happened . . ." (153; ellipsis in the original). The extent to which the narrator's queerness is understood is evinced in the spatial encounters and the implications of such violation of space explored in the text.

Although "Naked" offers a site in which the queer subconscious works in the performance of masculinity in In This City, "A Short Drive" further elucidates the extent to which spatialized homosocial 
encounters become queered as the tenuous nature of masculinity is tested against the very anxieties and insecurities that these intimacies among men produce. "A Short Drive" follows two men, Jack, a visiting professor from Toronto, and his student Calvin, a Georgian native, along their excursions through the American South. The shifting subjects of narrative and dialogue suggest a largely nihilistic space in the form of the $\operatorname{car}^{4}$ and, subsequently, the night club. These spaces as well as the homosocial encounters throughout the story are marked by immense ambiguities that act as sites in which queer desires are revealed subconsciously through spatiality. In the story, the American South is positioned as a site of queer possibilities for black men despite histories and narratives that say otherwise. 5 Calvin's note that "Southern trees bear strange fruit" and his mention of "Black bodies hanging in the Southern breeze" (130) might initially appear, especially the latter, to signify a racialized history, but recognition of the body as a site of strangeness, and a form of fluidity, is pertinent in reading the evolution of both masculinities and queer encounters in the text. Clinton Hutton suggests that lynching is an inherently queer activity and that the act often represents a transfer of power from the black male victim to the white male lyncher in much the same way that "Jamaican men consume 'cow cod soup' made from the bull's penis, believing that by so doing they will assume the perceived super-virility (bullishness) of that ultimate expression of masculinity" (31).

Despite the underlying ironies in their discourse, whatever queerness might exist in the homosocial encounter between Jack and Calvin is largely understated; rather, there seems to be more tension in their relationship largely evinced in the hypermasculine gestures of Calvin, such as smoking and drinking, in which the narrator does not partake. He merely observes Calvin's actions, and the only moment that could be queered is his observation of Calvin as he urinates: "A splattering of water hits the gravel. I imagine steam rising. I can smell the sting of the water. And then I too get out and shake my legs, each one to straighten the seams of my tight-fitting jeans. Calvin is still peeing and shaking. Some men can pee as long as horses. But it looks more as if he is being shaken by the peeing, in short spasms of delight and relief" (138-39). But this moment, which can be read as queered, is followed by a swift shift in Jack's observation of the radio and a song being played. Fundamentally, these shifts and the surreal moments of the men in 
the car on the road can be read as signs of insecurity and anxiety, of hyperaware men trying to read each other and match their performances of masculinity at various points. This falls in line with Rinaldo Walcott's view that black masculinity not only requires "a performance of bravado" but also asks its performers to "access the often threatening circumstances in which they find themselves in order to configure the range of the performance" ("Fragments" 361). Walcott goes on to suggest that queer spaces for black men exist as spaces in which "the tensions between these extremes are often quite evident" (361).

In "A Short Drive," these tensions emerge in the form of a shared psychosis that is linked to the spaces in which these men encounter each other and results in linguistic excess evident in hypermasculine postures of cursing, homophobic slurs, and aggression. The homosocial bond necessitates such performative gestures, as Diana Sargent notes: "[T] he more closely men associate, the more they are apt to express a hatred and fear of homosexuality; male homosociality seems to require extreme homophobia" (11). This is evident at the end of the story when an explicitly queer act is met with eventual condemnation because the linearity of hypermasculine expression is broken through a subconscious transgression when Jack kisses a transgendered person.

Like "Initiation," "A Short Drive" centres on a teacher-student relationship inverted because of space. Calvin, a native of the American South, claims the space as an impetus for his bravado and hypermasculine expression. Inversion of the archetypal relationship is the first sign of queerness in the story as the space becomes one recognized for changing the established models of relating among men. Jack makes it clear early that "Calvin was my student. . . . [H] e became my guide to where the action was, and almost my friend" (127). The word almost reinforces my reading of tension between the men and how their relationship is marked by a sense of vulnerability in not knowing the gestures and established rituals of masculine interactions. The car, a symbol of masculinity and the "cool pose" invoked earlier, becomes a site of masculine ambiguity. The notion of lack of boundaries in the homosocial encounter is explored in the space of the car and the road. Justin Wyatt's work on the homosocial points to a distinct need for "boundaries drawn between the homosocial and the homosexual" (qtd. in Sargent 11) in descriptions of male relationships to distinguish between what is normative and what is not. However, in "A Short Drive," the 
boundaries have failed to be established, and what results is not so much the queer emerging out of the homosocial as the act of revealing the existing homosexual and fluid nature of these relationships among men and their inability to remain strictly heteronormative. The narrator's remark that "driving along this road, in the middle, there was no dividing line, and if there was we could not see it" (136), reinforces the idea of liminality in the narrative that will culminate in an ultimate transgression of heteronormative masculinity. The ambiguities of both spatial and homosocial expression in the narrative result in what can be characterized as homosexual panic in the men. More specifically, a shared psychosis that arises from both a spatial and a gendered milieu is best articulated as "a flight from full individuality (because it might at certain points embrace the reprobated patterns of homosexuality) for the safety of traditional roles that do not threaten the enabling fictions of gender distinction" (qtd. in Skeete 12).

The space of the Stallion Club that Calvin visits with Jack emerges as the site in which the ambiguities of homosociality and homosexuality evident in the space of the car culminate. Corey K. Creekmur and Alexander Doty argue that "Homosociality is contradictorily located on two extremes of the spectrum, with the allowance of either explicit homosexual desire on one end or homophobia on the other, and the spaces in which this occurs are inherently segregated boys clubs" (qtd. in Sargent 11). The Stallion Club, as its name suggests, signifies a rough masculinity. Thus, it is ironic that this space is marked by explicit queerness in the form of drag queens, transsexuality, and homosexuality. The narrator's encounter with the space is rooted in a purely sexual response that begins to reveal Jack as a queered figure. In the club, he dances with women and begins to engage in a sensuous encounter until Calvin intervenes and unmasks one of the women, Clovis, and reveals her to be transgendered. More than making a spectacle of the transgendered figure, the revelation foregrounds the narrator's queered self. Moreover, this incident is interesting because of the initial (non-)response of Calvin, who views the intimacy between Jack and the queered figure as they dance without raising an alarm in the typical normative heterosexual and homophobic manner. Indeed, Jack notes that when he danced with Clovis, "Calvin was there to witness my surrender, and . . . live to tell the story" (144). Calvin does nothing at that point to interrupt the two, suggesting that these queer intimacies among men 
are not unusual, indeed acknowledged and affirmed in that space, until they become materialized through a near-sexual encounter. Desire for another man or dancing with a transgendered woman is normalized in the space of the Stallion Club. Clovis makes an important linguistic disclosure that implicates the heterosexual Calvin, noting that "he [Jack] ... weren't one of us, weren't from the South" (146). This implication does significant work in constructing the queered nature of these men and homosocial encounters in both the Stallion Club and the South. The space represents the masculine figure, once again as enacting a form of marronage by operating within the dark and within a subjectivity that makes heteronormative assumptions about the self when in fact a queered reality is always present.

Irony prevails in many of Clarke's characterizations of masculinity. His male characters are often confident, highly animated, occasionally misogynistic, and mostly insistent on their right not merely to exist in spaces but also to take up spaces. However, the irony that pervades the relationships of these men with different spaces is evident in how they are positioned by the spaces as opposed to exercising power and effecting change within the spaces. Clarke uses homosociality as well as spatiality as modes of mediating the process of uncovering and recovering the queer possibilities of transnational black masculinities by positioning men as overexposed and insecure, often by their own doing. His focus on homosocial encounters demonstrates how homosocial communal gatherings are manufactured responses by black male subjects in order to escape and invert the dominating codes of hypermasculinity and the often essentializing raced, gendered, and sexualized politics of external hegemonic white spaces. It is in these alternative spaces of masculine gathering that men find themselves as reluctantly queered subjects. For Clarke, spaces of homosociality allow for the dismantling of heteronormative masculine performances and for the undertaking of queered expressions. This queer experience is not a matter of suppression or conscious engagement; rather, it sneaks up on the subjects as something that they never thought possible, yet it is entirely permissible in the spaces that they inhabit with other men. Masculinities in In This City, and in the wider work of Austin Clarke, are constantly on the move, resisting fixity and exemplifying how spaces are claimed, inhabited, and felt by men who strive for recognition, safe spaces, and a nation to claim as their own. 


\section{Author's Note}

My deepest gratitude to Michael Bucknor and Lisa Brown, who shaped in starkly different ways my understanding of Clarke's work. Thanks also to the Department of Literatures in English at the University of the West Indies at Mona for allowing me to present an earlier version of this article as part of its Staff/Postgraduate Seminar series and for the feedback and support kindly offered to me in the spirit of collegiality. I am also grateful to the two anonymous readers of this article; I highly appreciated their generous comments.

\section{Notes}

${ }^{1}$ This positioning of Canada as a more liberated space is also evident in Clarke's novel The Survivors of the Crossing (1964). The protagonist, Rufus, receives letters from his friend Jackson, living in Canada, who describes the country as "a real first class place!" Jackson goes on to write, "I sure, sure that the word Canada mean something like progressiveness!" (31).

${ }^{2}$ Discourses of marronage have emerged within black studies and have their origins in the term "maroon," which refers to those who escaped slavery within the Americas and formed communities separated from slave societies. The more contemporary usage of the term "marronage" usually refers to "petit marronage," which "refers to a strategy of resistance in which individuals or small groups, for a variety of reasons, escaped their plantations for a short period of days or weeks and then returned." Conversely, "grand marronage" "refers to people who removed themselves from their plantations permanently" (Kars).

${ }^{3}$ This homosocial structure of masculinity is evident in other works by Clarke. In Proud Empires, the rum bar is another site for "initiation" for younger men. In The Origin of Waves, the male protagonists also recall their pasts in Barbados, where older men bring boys into manhood through various rituals. The lament of the title There Are No Elders and the repetition of "Elder-less" in In Your Crib also point to this sense of homosocial elder-student relations.

${ }^{4}$ The car is a major site of masculinity in Clarke's work. In The Meeting Point, cars function as representations of masculinity. The "blasted old Boer-war Chevvy" (65) allows Boysie to feel a sense of masculine pride and status in spite of his wife's financial success and dominance. Moreover, it operates as a site of homosociality in The Meeting Point in which Boysie and Henry discuss women and their own desires.

${ }^{5}$ This is not to suggest that a queer presence in the American South is impossible or non-existent. Metropolitan spaces such as Orlando and Atlanta are regarded as relatively safe spaces for LGBTQ people of colour. However, beyond these urban areas, the representation of queer people of colour is limited. As Bernadette Barton notes, American Southern "attitudes create and maintain a homophobic status quo. Conventions of small-town life, rules that govern southern manners, and the power wielded by Christian institutions and Christians within secular institutions all serve as a foundation for both passive and active homophobia" (4). 


\section{Works Cited}

Antwi, Phanuel. "Rough Play: Reading Black Masculinity in Austin Clarke's 'Sometimes, a Motherless Child' and Dionne Brand's What We All Long For." Studies in Canadian Literature, vol. 34, no. 2, 2006, pp. 194-222, journals.lib.unb.ca/index.php/SCL/ article/view/12708.

Barrett, Paul, et al. "The Unbearable Whiteness of CanLit.” The Walrus, 26 July 2017, thewalrus.ca/the-unbearable-whiteness-of-canlit/.

Barton, Bernadette. Pray the Gay Away: The Extraordinary Lives of Bible Belt Gays. New York UP, 2014.

Brand, Dionne. In Another Place, Not Here. Vintage Canada, 1997.

Bucknor, Michael A. "Austin Clarke, Affective Affiliations, and the Cross-Border Poetics of Caribbean Canadian Writing." Beyond "Understanding Canada": Transnational Perspectives on Canadian Literature, edited by Lorraine York et al., U of Alberta P, 2017, pp. 51-77.

Butler, Judith. Gender Trouble: Feminism and the Subversion of Identity. Taylor and Francis, 2002.

Chariandy, David. Introduction. Clarke, In This City, pp. ix-xv.

Clarke, Austin. In This City. 1992. Exile Editions, 2008.

-. In Your Crib. Guernica, 2015.

-. The Meeting Point: The Toronto Trilogy. 1967. Ian Randle, 2005.

—. 'Membering. Dundurn, 2015.

-. The Origin of Waves. McClelland \& Stewart, 1987.

-. Proud Empires. London: Gollancz, 1986.

-. The Survivors of the Crossing. Peepal Tree Press, 2011.

—. There Are No Elders. Exile Editions, 1993.

Coleman, Daniel. Masculine Migrations: Reading the Postcolonial Male in "New Canadian" Narratives. U of Toronto P, 1998.

Cummings, Ronald. "Queer Theory and Caribbean Writing." The Routledge Companion to Anglophone Caribbean Literature, edited by Michael A. Bucknor and Alison Donnell, Routledge, 2011, pp. 323-31.

Dennis, Richard, and Coral Ann Howells. "Geography, Gender, and Identity in Canadian Literature: Some Introductory Comments." The London Journal of Canadian Studies, vol. 12 , no. 1,1996 , pp. 1-5.

Hutton, Clinton. "The Gyalification of Man: The Expression of Male-Male Conflict in Jamaica and the Roots of Homoeroticism in Political Ideology, Ontology, and Praxis of White Supremacy." Caribbean Quarterly, vol. 60, no. 4, 2014, pp. 21-45.

Kars, Marjoleine. "Maroons and Marronage." Oxford Bibliographies, Oxford UP, 15 Feb. 2018, www.oxfordbibliographies.com/view/document/obo-9780199730414/obo9780199730414-0229.xml\#firstMatch.

Kramer, Beth Ellen. "'Postcolonial Triangles': An Analysis of Masculinity and Homosocial Desire in Achebe's A Man of the People and Greene's The Quiet American." Postcolonial Text, vol. 4, no. 4, 2008, pp. 1-14.

Majors, Richard, and Janet Mancini Billson. Cool Pose: The Dilemmas of Black Manhood in America. Touchstone, 1992.

Milan, Anne, and Kelly Tran. "Blacks in Canada: A Long History." Canadian Social Trends, vol. 72, 2004, pp. 2-7.

Najmabadi, Afsaneh. Women with Mustaches and Men without Beards: Gender and Sexual Anxieties of Iranian Modernity. U of California P, 2010. 


\section{SCL/ÉLC}

Ortega, Mariana. "Exiled Space, In-Between Space: Existential Spatiality in Ana Mendieta's Siluetas Series." Philosophy and Geography, vol. 7, no. 1, 2004, pp. 25-41.

Price, Carolyn E. "Legacy of Bill C-150 in Canada 40 Years Later." Digital Journal: A Global Digital Media Network, 14 May 2009, www.digitaljournal.com/article/272614.

Sanders, Leslie. "Dear Austin: Why Teaching Your Work Is Difficult." The Puritan, 6 Aug. 2017, http://puritan-magazine.com/dear-austin/.

Sargent, Diana. "American Masculinity and Homosocial Behavior in the Bromance Era." ScholarWorks, Georgia State U, 2013, scholarworks.gsu.edu/cgi/viewcontent.cgi?arti cle $=1099 \&$ context $=$ communication_theses.

Sedgwick, Eve Kosofsky. Between Men: English Literature and Male Homosocial Desire. Columbia UP, 1985.

Skeete, Geraldine. "Representations of Homophobic Violence in Anglophone Caribbean Literature." Caribbean Review of Gender Studies, vol. 4, 2013, uwispace.sta.uwi.edu/ dspace/handle/2139/16036?show=full.

Walcott, Rinaldo. "Fragments of Toronto's Black Gay Community: From a Life Still Being Lived." Our Caribbean: A Gathering of Lesbian and Gay Writing from the Antilles, edited by Thomas Glave, Duke UP, 2008, pp. 360-67.

—. "'A Tough Geography': Towards a Poetics of Black Space(s) in Canada." Black Like Who: Writing Black Canada, Insomniac, 1997, pp. 35-52.

X, Malcolm. "Speech to Peace Corps Workers (December 12, 1964)." Malcolm X Files, malcolmxfiles.blogspot.ca/2013/07/speech-to-peace-corps-workers-december.html. 